\title{
Response of Sucking Insect Pest Fauna Towards Bt and Non Bt Cotton Genotypes under Varying Climatic Condition
}

\author{
Tamoor Ali ${ }^{1 *}$, Muhammad Hamid Bashir ${ }^{1}$, Bilal Saeed Khan ${ }^{1}$, Abdul Ghaffar ${ }^{2}$, Danish Riaz ${ }^{3}$, Muhammad \\ Zia ul Haq ${ }^{1}$, Shoaib Nawaz ${ }^{1}$, Aneeb Ali ${ }^{1}$, Iftikhar ul Hassan', Ikram U1 Haq ${ }^{4}$, Muhammad Khuram \\ Shahzad $^{1}$, Usama Saleem ${ }^{5}$ and Tamsila Nazir ${ }^{2}$
}

${ }^{1}$ Department of Entomology, University of Agriculture, Faisalabad, Pakistan; ${ }^{2}$ Ayub Agriculture Research Institute, Faisalabad, Pakistan; ${ }^{3}$ Department of Zoology, Division of Science and Technology, University of Education, Lahore, Pakistan; ${ }^{4}$ Department of Pest Warning and Quality Control of Pesticides, Punjab, Pakistan; ${ }^{5}$ Department of Zoology, Government College University, Faisalabad, Pakistan.

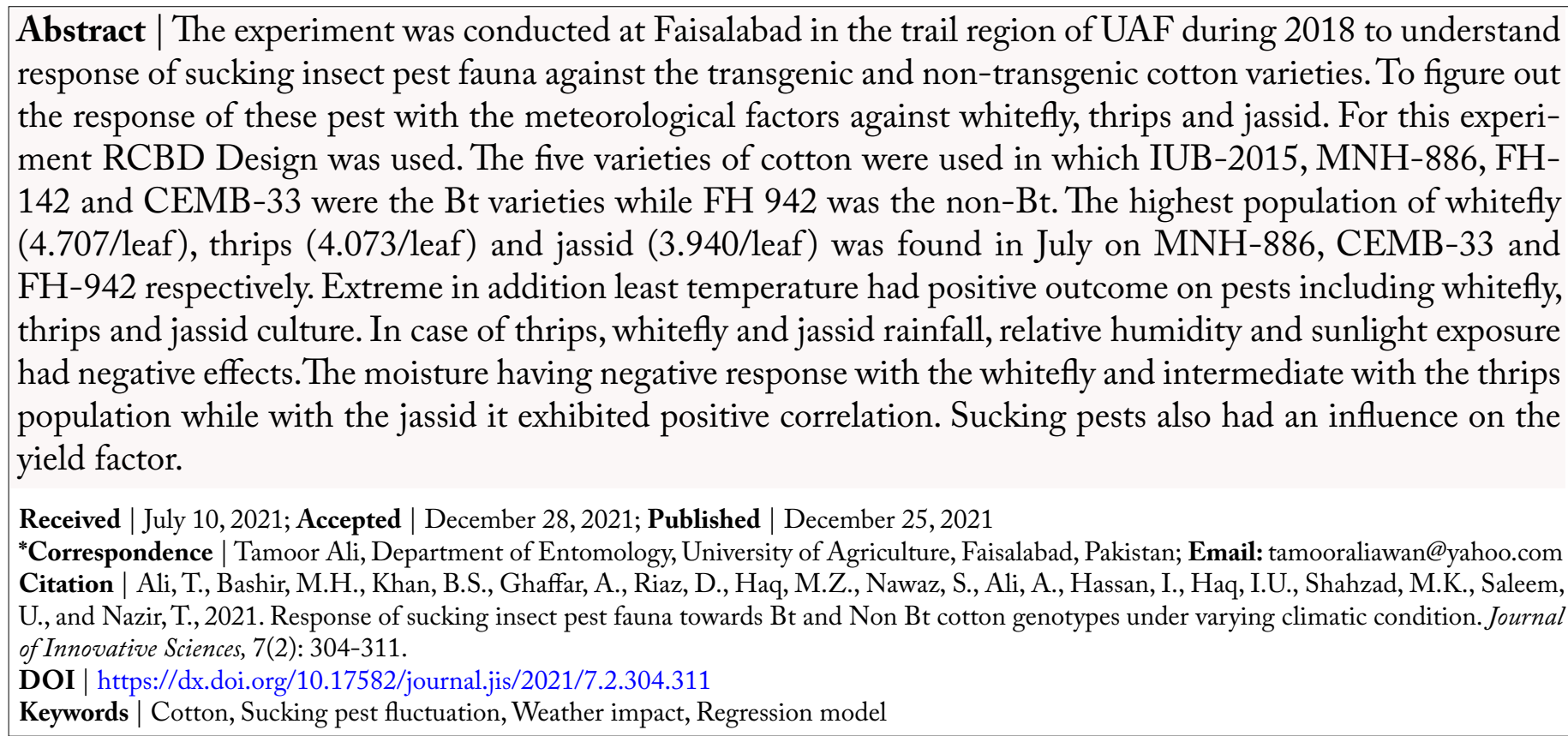

\section{Introduction}

A bout $18 \%$, agriculture contributes in Gross Domestic Product (GDP). Cotton has $0.8 \%$ share in the economy and $4.5 \%$ in the agriculture values of Pakistan. Cotton is an important crop that's why it is believed as the lifeline of the Pakistan (Anonymous, 2018). Cotton is the world's most important fibrous crop and it grows in both tropical and sub-tropical areas of universe (Bala et al., 2019). Throughout the year of 2018 and 2019, the cotton production keeps on at 9.861 million bales. Sometime the production of the crop was also affected by meteorological factors. The production of the cotton crop in 2019 remained at the $2373 \mathrm{Ha}$ while the yield was $606 \mathrm{Kgs} / \mathrm{Ha}$. Textile is the major sector of the Pakistan. The exports of the cotton and cotton textile during 2019 from July-March remained at 9771 US Million dollars (Anonymous, 2018). Pakistan is at $4^{\text {th }}$ after US, China and India in case of cotton production (Anonymous, 2018). In between sucking pests of cotton; whitefly, jassid, thrip, recorded as greatest damaging pests (Arif et al., 2006; Ali and Aheer, 2007; Salman et al., 2011). Lint quality and 
the quality deteriorate and gradually decrease due to the attack of sucking pests (Amin et al., 2008; Shah, 2014). The stats told that during the previous years the whitefly was the major pest of crop which causes damage (Ali et al., 1993; Aheer et al., 1999). Due to this some disease also transferred to the cotton crop (Harrison et al., 1997).

jassid on the other hand, has played a significant influence in the destruction of cotton plants (Gupta et al., 1997; Inee-Gogoi et al., 2000).

For the management of insect pest, the cotton genotype grows in specific condition of climate (Ali and Aheer, 2007; Amin et al., 2008; Yousafi et al., 2013). Additionally, it is seen that different aspects like $\mathrm{RH}$, temperature and precipitation also support in the expansion and fluctuation of cotton's pest as documented in initial studies (Aheer et al., 1994; Mohapatra, 2008; Akram et al., 2013). The population of jassid increases by the temperature and humidity. (Inee-Gogoi et al., 2000). Ali et al. (1993) explained that temperature disclosed a significant and positive role for jassid population $\mathrm{r}=0.297$ and precipitation presented adverse and significant effect $r=0.483$, while the consequence of $\mathrm{RH}$ was non-significant.

In the same way, it is studied that the influence of rainfall, temperature and humidity having fifty percent impact on whitefly, jassid and thrips populace (Arif et al., 2006; Mohapatra, 2008; Akram et al., 2013).

The contemporary study was directed to determine the attraction of sucking pest towards four $\mathrm{Bt}$ and one non-Bt cotton genotypes. Furthermore, the effect of temperature, sunshine duration, rainfall and $\mathrm{RH}$ also recorded on these genotypes. All this experiment was conducted under unsprayed condition in the region of Faisalabad.

\section{Materials and Methods}

The research was conducted in the University of Agriculture trials area in Faisalabad, Pakistan in 2018. The climatic condition of the Faisalabad region is very hot during the summer. Investigated the genotypes IUB-2015, MNH-886, FH-142, CEMB-33 and $\mathrm{FH} 942$. FH 942 was the non Bt variety while the other was the Bt varieties. Experiment was designed under randomized complete block design with three replications. Field was divided into 15 plots and dimension of small plot was $6 \times 10 \mathrm{ft}$. R-R and P-P distance remained at $2.5 \mathrm{ft}$ and $30 \mathrm{~cm}$, respectively. Seed were sown in start of May by using the dibbling method. Data regarding the whitefly, thrips and jassid was noted on per leaf basis once a week at morning time between the 5:00 am to 6:30 am at lower surface of leaf. The data regarding the meteorological factors was taken from the Crop Physiology Department, University of Agriculture, Faisalabad, Pakistan. R software was used for the analysis of data.

\section{Results and Discussion}

\subsection{Whitefly}

The cumulative data showed the average population whitefly was maximum (4.707) was recorded on 12July 2018 while the lowest population (0.487) was recorded on 11-October 2018 in Figure 2. Different cotton varieties showed different level of population of whitefly. In all varieties of cotton, the maximum population was recorded in July while the lower density was recorded in October in Figure 1.

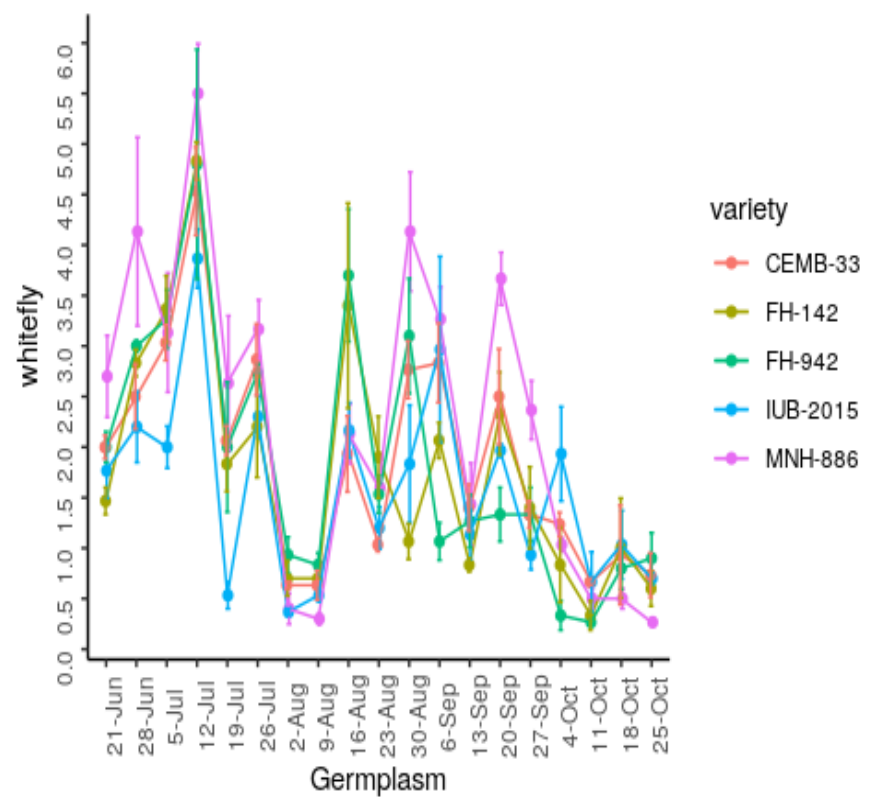

Figure 1: Relationship between different population of whitefly and cotton germplasm.

Khanzada et al. (2016) detected that the populace of whitefly was highest in July $(24.45 \pm 0.15)$. Temperature and humidity show a vital part in increasing the population of whitefly. Maximum population of whitefly was recorded MNH-886, FH-942, CEMB33, FH 142 and IUB 2015, respectively in Figure 3.

The relationship of whitefly population showed the FH-142 it displayed the positive relationship 


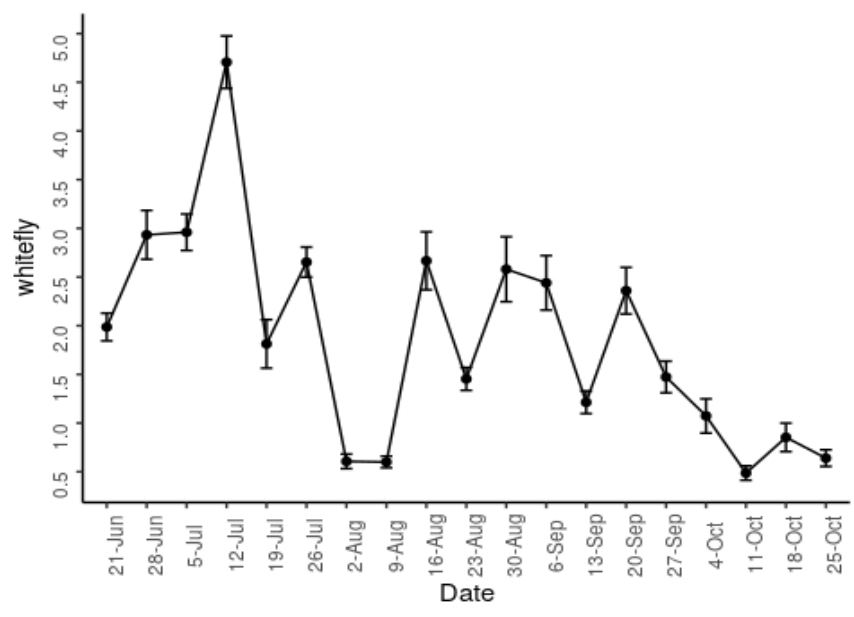

Figure 2: Fluctuation of population of whitefly in different date of observation

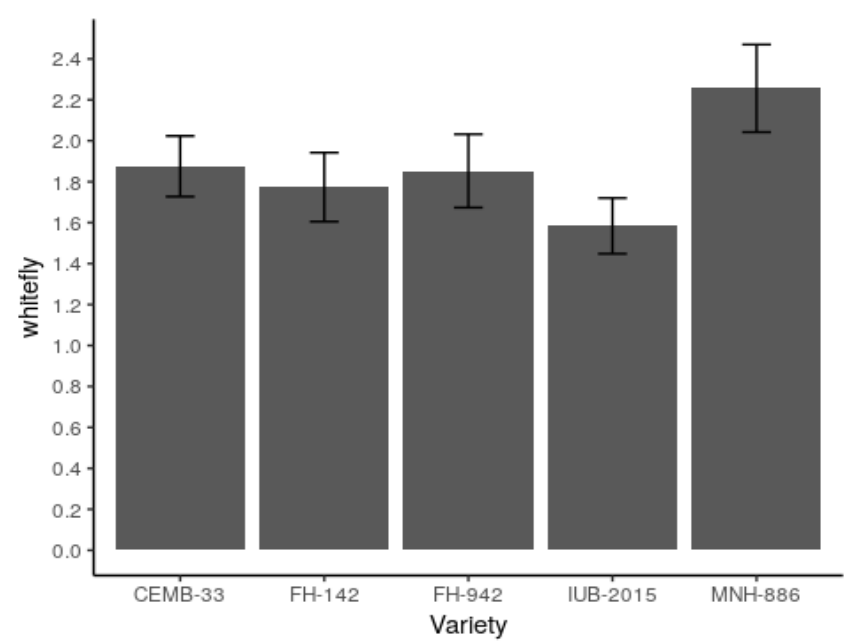

Figure 3: Comparison of population dynamics of whitefly among varieties of cotton crop.

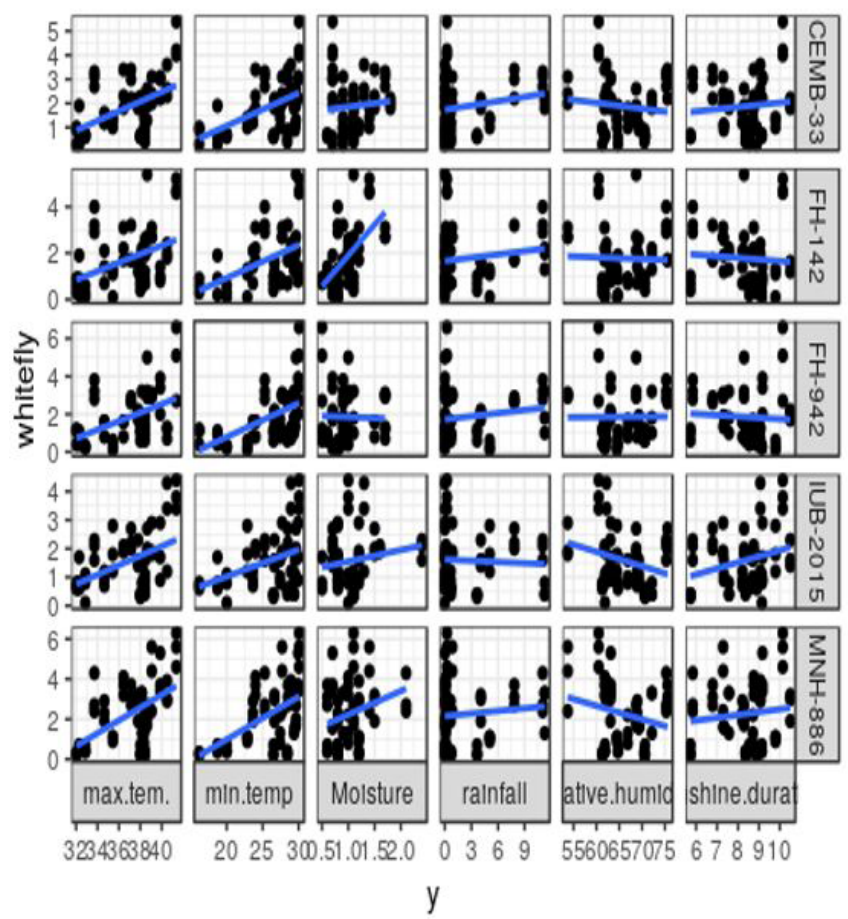

Figure 4: Relationship of whitefly population with abiotic factors in different cotton cultivars with the least in addition extreme temperature and moisture while the adverse showed with the rainfall, relative humidity and sunshine duration. CEMB33, IUB-2015, MNH-886 and FH-942 exhibited positive relationship with maximum temperature, minimum temperature while negative exhibited with the moisture, rainfall, relative humidity and sunshine duration in Figure 5. Saleem et al. (2018) conducted a similar study in which it is revealed that the maximum population was recorded on MNH 886 which is the cotton variety and also explained that temperature is directly proportional to temperature while negative response was observed with the relative humidity and rainfall.

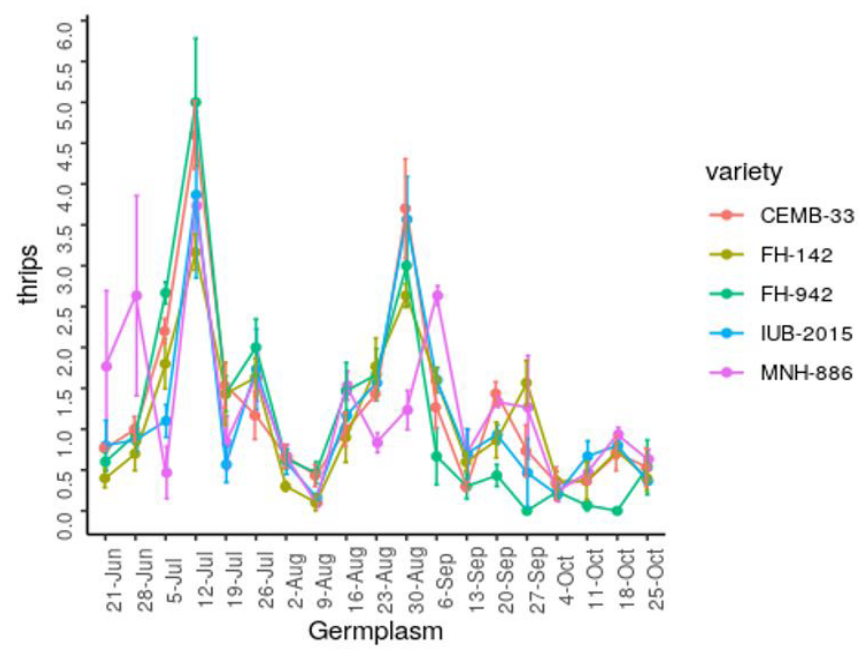

Figure 5: Relationship between population of thrips and cotton germplasm

\subsection{Thrips}

The cumulative data showed the average population thrips was maximum (4.073 per leaf basis) population was recorded in 12-July while the lowest population (0.253 per leaf basis) was recorded on Aug after that again the population buildup and then in October again the population was at its lower level (0.273 per leaf basis) in Figure 6. Different cotton varieties showed different level of population of thrips. In all varieties of cotton, the maximum population was recorded in July while the lower density was recorded in August and October Figure 5. Maximum population of thrips was recorded CEMB-33, MNH886, FH-942, FH-142, IUB-2015 respectively in Figure 7. Correlation of thrips population with the abiotic factors displayed that in CEMB-33, FH-142, FH-942, IUB-2015 and MNH-886 had positive relationship with the maximum temperature and the minimum temperature while the other factors including moisture, rainfall, relative humidity and

Journal of Innovative Sciences

December 2021 | Volume 7 | Issue 2 | Page 306 
sunshine duration showed the negation link in Figure 8. Khanzada et al. (2016) revealed that the population of thrips was at its peak position $(15.60+0.78)$ in July and meteorological factors temperature and relative humidity also played an important role in increasing the population. Ashfaq et al. (2010) reported that maximum jassid population start buildup in July and it has positive correlation with the temperature while relative humidity and rainfall had negative effect.

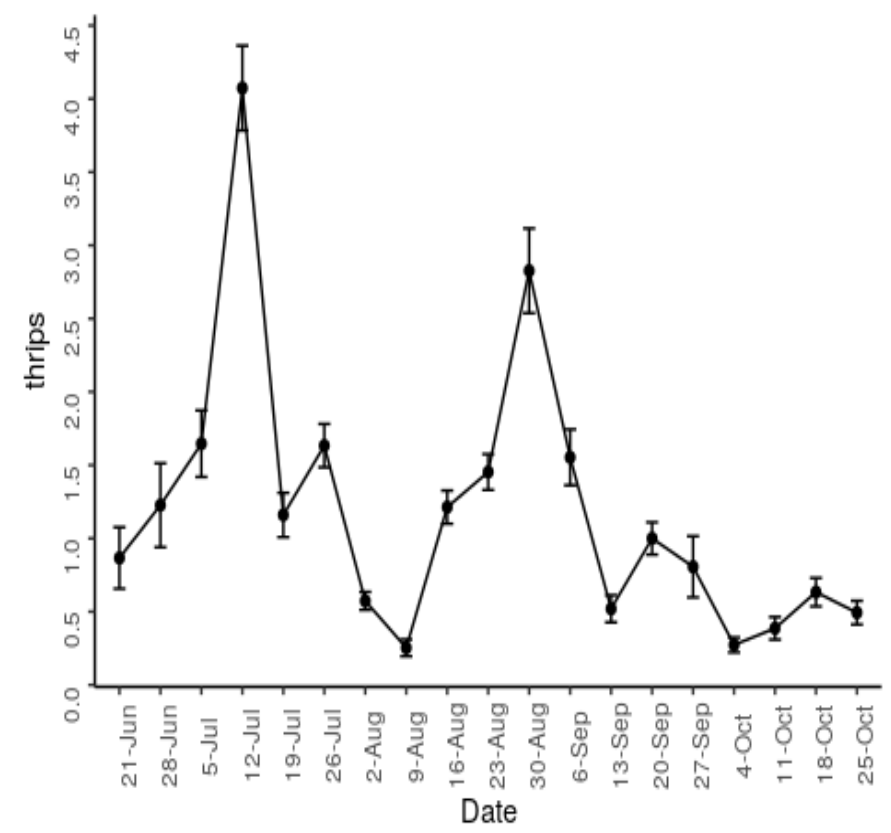

Figure 6: Fluctuation of population of thrips in different date of observations

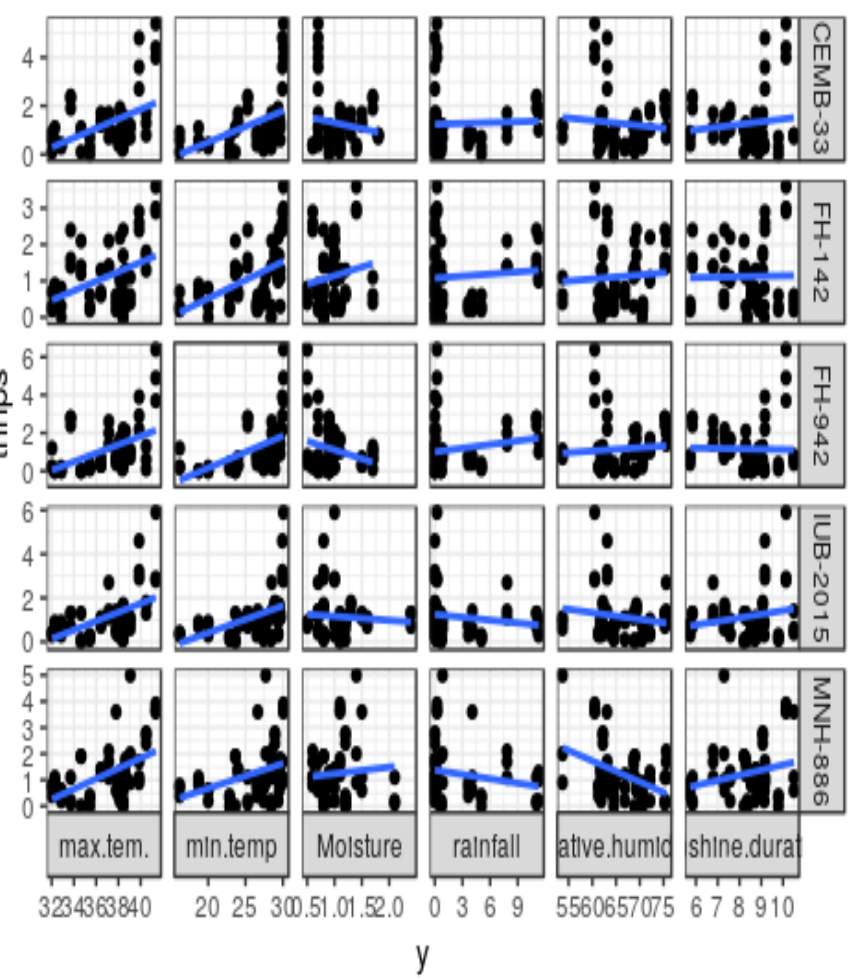

Figure 7: Relationship of thrips population with abiotic factors in different cotton cultivars



Figure 8: Comparison of population dynamics of thrips among varieties of cotton crop

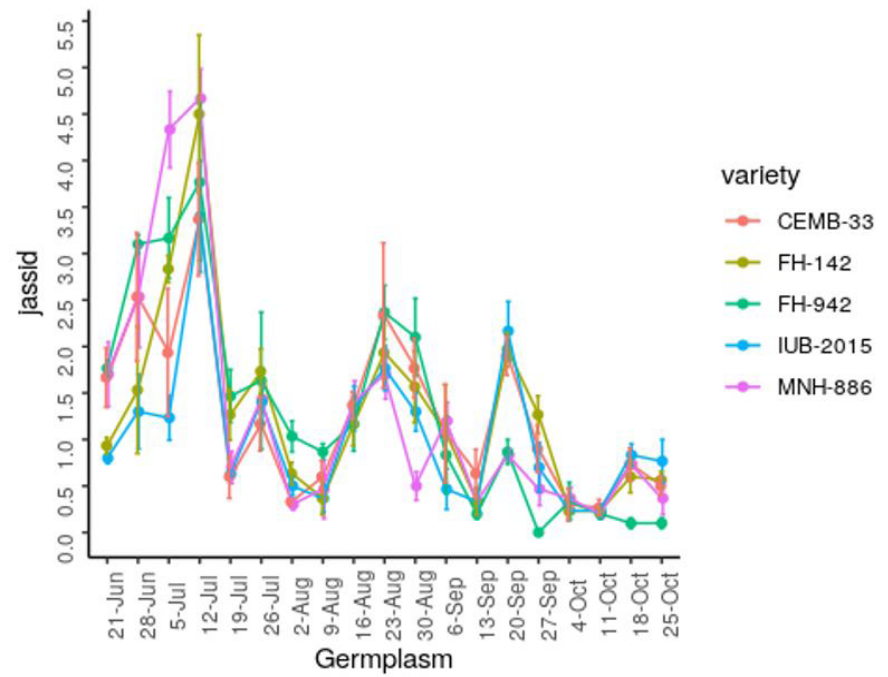

Figure 9: Relationship between population of jassid and cotton germplasm

\subsection{Jassid}

The cumulative data showed the average population jassid was maximum (3.940 per leaf basis) population was recorded in 12-July while the lowest population (0.227 per leaf basis) was recorded on October in Figure 10. Different cotton varieties showed different level of population of jassid. In all varieties of cotton the maximum population was recorded in July while the lower density was recorded in October in Figure 9. Maximum population of jassid was recorded $\mathrm{FH}-$ 942, FH-142, MNH886, CEMB-33, IUB-2015, respectively Figure 11 . Correlate the population of jassid with the abiotic factors displayed that CEMB33, FH-142, FH-942, IUB-2015 and MNH-886 had positive relationship with the maximum temperature, 
minimum temperature, moisture level, rainfall while the negative showed with the relative humidity and sunshine duration in Figure 12. Similar type of work done by the Salman et al. (2011) in which it was observed that the six cotton varieties grown in the NIAB, Faisalabad had maximum population of jassid in $3^{\text {rd }}$ and $4^{\text {th }}$ week of July. Arif et al. (2006) reported that the temperature and rainfall had positive relationship while the relative humidity had negative relationship. Mahmood et al. (2002), who reported about the correlation effect. It is observed that highest and the least temperature was positively correlated although relative humidity and rainfall was negatively linked.

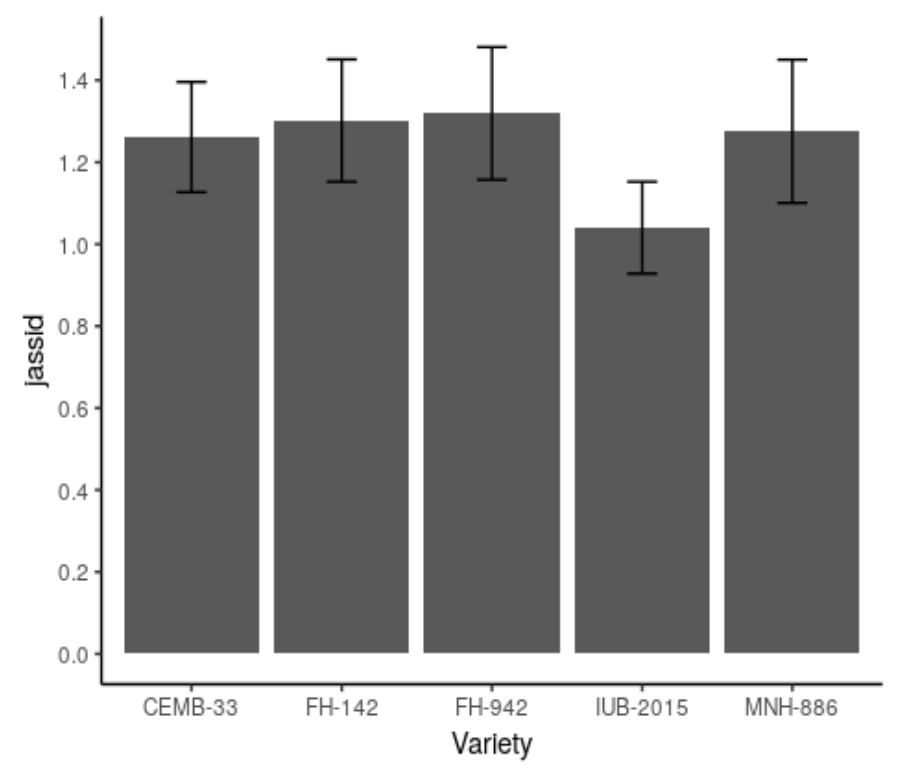

Figure 10: Comparison of population dynamics of jassid among varieties of cotton

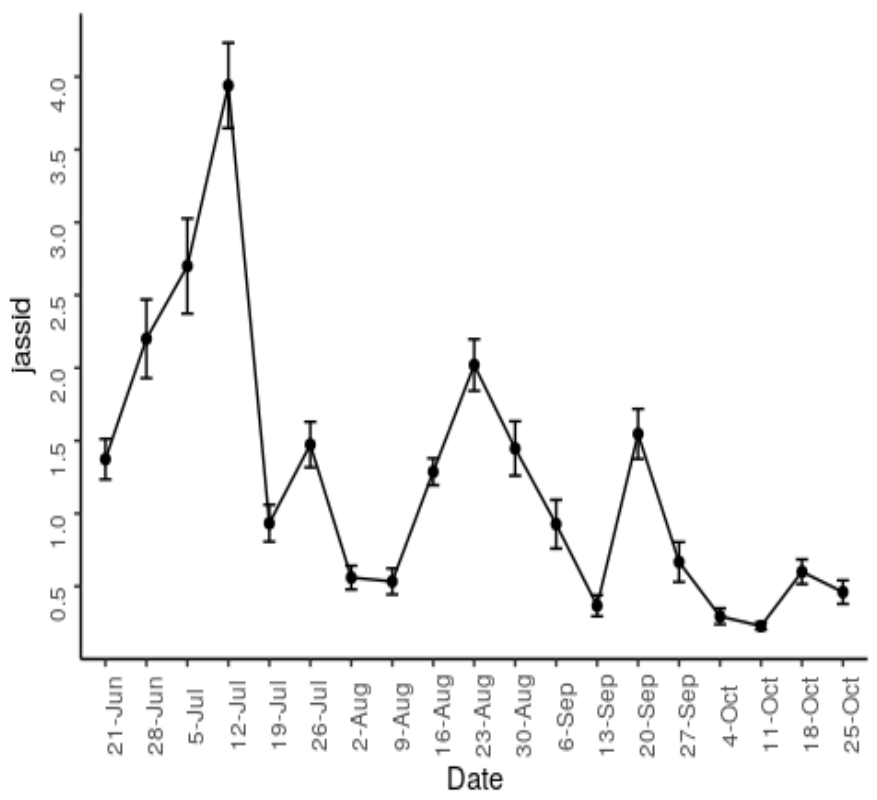

Figure 11: Fluctuation of population of jassid in different date of observation

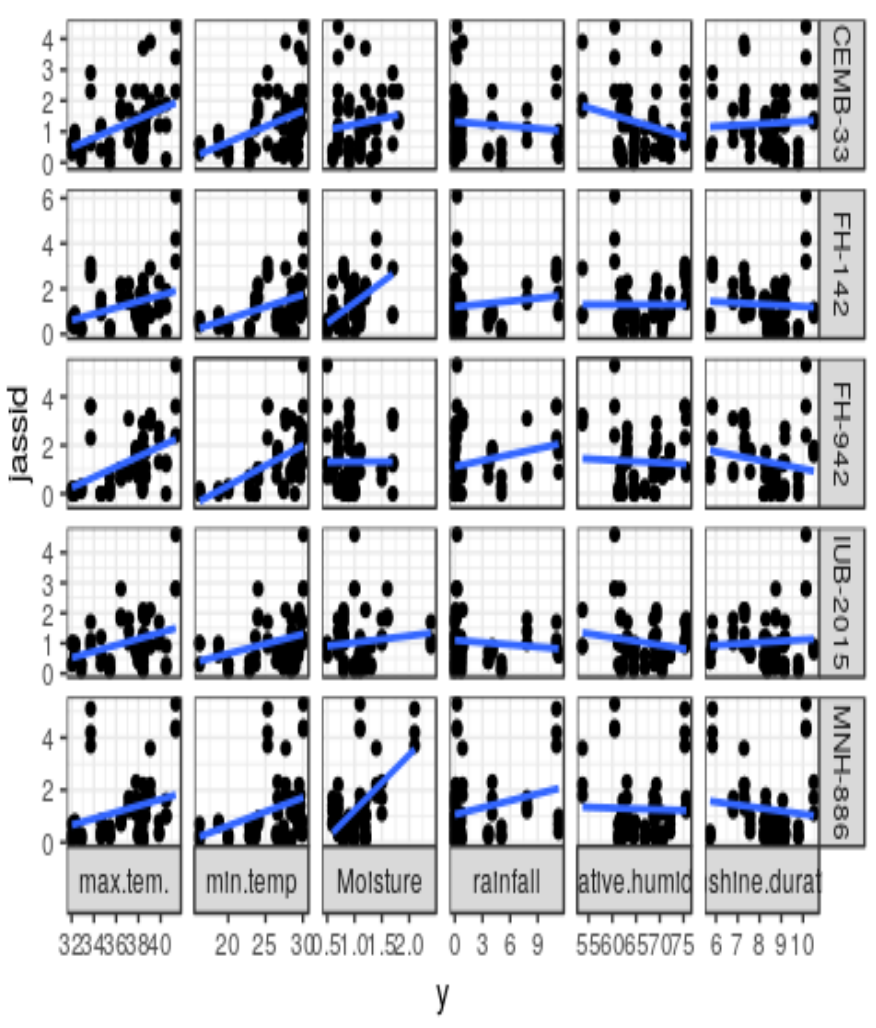

Figure 12: Relationship of jassid population with abiotic factors in CEMB-33

\subsection{Regression studies and yield}

Based on regression study by taking sucking pest population "Y" as dependent variable while weather parameters " $\mathrm{X}$ " as independent variables following equations were fitted for the year 2018. The population of whitefly $0.342,0.126,0.086,0.072,0.098 \mathrm{had}$ relationship with the minimum temperature, $\mathrm{RH}$, rain, light duration and moisture. The population of jassid increases with the $0.297,0.047,0.06,0.252$ and 0.252 per three leaves per week with the increase in the minimum temperature, rainfall, sunshine duration and with the moisture. Thrip's population $0.211,0.041$ and 0.058 increases with the minimum temperature, rainfall and sunshine duration (Table 1 ). The variable PCA Figure 13 tell us that moisture, minimum temperature jassid population, whitefly population, thrips population and maximum temperature had close relationship while the relative humidity and rainfall also having positive effect. The sunshine duration had negative relationship with the other factors. The Figure 14 showed that the population of pest having influence on the yield factor. This displayed that attack of whitefly (1.25 per leaf basis) , thrips (0.52 per leaf basis) and jassid (0.36 per leaf basis) had average yield of IUB-2015 was $1.19 \mathrm{~kg}$. The cotton variety FH-142 having average yield $1.23 \mathrm{~kg}$ with the attack of whitefly (1.12 per leaf basis), thrips 
(0.42 per leaf basis) and jassid (0.44 per leaf basis). The cotton variety $\mathrm{MNH}-886$ having average yield $080 \mathrm{~kg}$ with the attack of whitefly (0.91 per leaf basis), thrips ( 0.39 per leaf basis) and jassid (0.38 per leaf basis). The cotton variety CEMB-33 having average yield $1.25 \mathrm{~kg}$ with the attack of whitefly $(0.83$ per leaf basis), thrips ( 0.39 per leaf basis) and jassid ( 0.48 per leaf basis). The cotton variety $\mathrm{FH}-942$ having average yield $0.45 \mathrm{~kg}$ with the attack of whitefly $(0.75$ per leaf basis), thrips ( 0.35 per leaf basis) and jassid ( 0.21 per leaf basis).

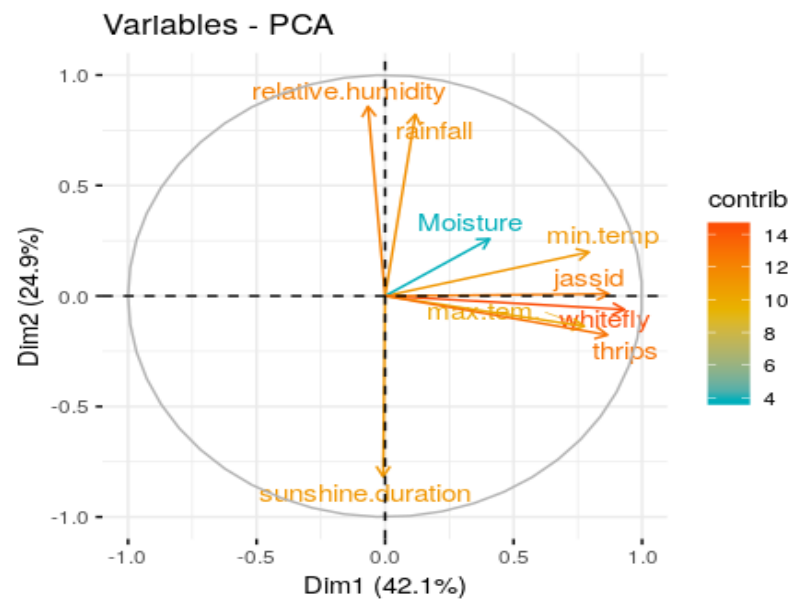

Figure 13: PCA Figure for environmental variation

Figure 14 : Yield data of different cotton varities with responce of sucking inset pests

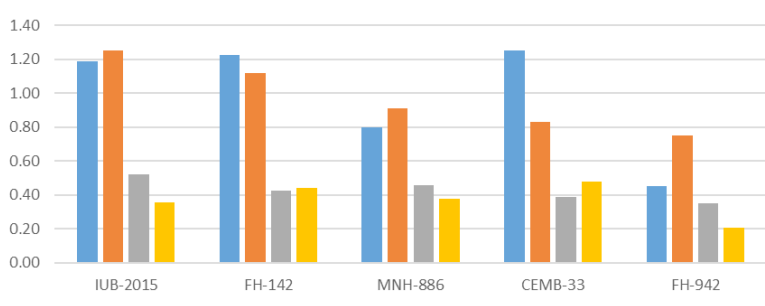

Vield EhhiteflyPopulation - Thrips - Jassid

Figure 14: Yield data of different cotton varities with responce of sucking insct pests.

\section{Conclusions and Recommendations}

This study was done to check the attack of whitefly, thrips and jassid on different cultivars of cotton crop under unsprayed condition. Results indicated that whitefly population was low on IUB-2015 as compared to other. Same result was found when thrips and jassid attack. Abiotic factors also played an important role. In case of whitefly, jassid and thrips minimum temperature, maximum temperature showed positive role while in case of jassid moisture level also had significant role.

\section{Table 1: Regression equation of sucking pests with weather parameters on Bt cotton and non-Bt cotton in Faisalabad region.}

\begin{tabular}{|c|c|c|}
\hline $\begin{array}{l}\text { Sucking } \\
\text { pests }\end{array}$ & Regression equation & $\begin{array}{l}R^{2} \\
\text { value }\end{array}$ \\
\hline Whitefly & 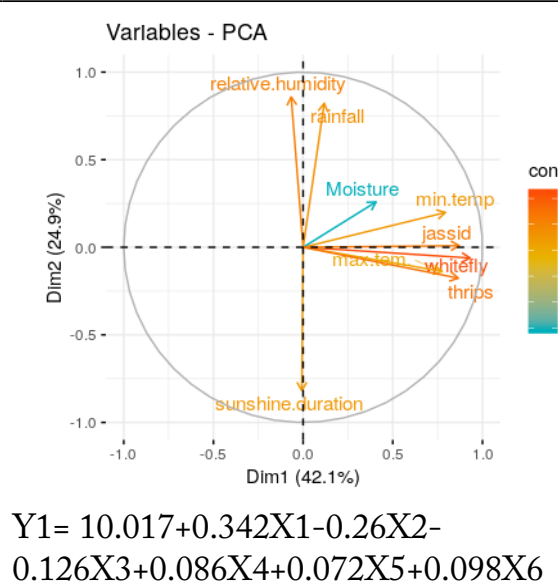 & 0.334 \\
\hline Jassid & $\begin{array}{l}\mathrm{Y} 1=10.842+0.297 \mathrm{X} 1- \\
0.271 \mathrm{X} 2-0.109 \mathrm{X} 3+0.047 \mathrm{X} 4- \\
0.06 \mathrm{X} 5+0.252 \mathrm{X} 5+0.252 \mathrm{X} 6\end{array}$ & 0.266 \\
\hline Thrips & $\begin{array}{l}\mathrm{Y} 1=04.054+0.211 \mathrm{X} 1-0.097 \mathrm{X} 2- \\
0.072 \mathrm{X} 3+0.041 \mathrm{X} 4+0.058 \mathrm{X} 5-0.585 \mathrm{X} 6\end{array}$ & 0.277 \\
\hline
\end{tabular}

\section{Acknowledgements}

This work would not have been possible without the support of the worthy supervisor Dr. Muhammad Hamid Bashir. I am also indebted to Dr Abdul Ghaffar, Agricultural Research Officer, Ayub Agriculture Research Institute, Faisalabad, Pakistan and Muhammad Zia-ul-Haq, who have actively worked to provide me with protected academic time to pursue my professional goals and who have been supportive of my career ambitions. I am thankful to everyone who work and help during this scientific study.

I would especially like to thank respected Dr. Muhammad Hamid Bashir, the chairman of my committee. He taught me more than I could ever give him credit for as my teacher and mentor. $\mathrm{He}$ has demonstrated what a good scientist (and person) should be through his activities. The members of my family have been more valuable to me in the pursuit of this project than anybody else. I am thankful to my fellows, Aneeb Ali, Shoaib Nawaz, Iftikhar-ul-Hasan who provide unending inspiration.

\section{Novelty Statement}

The experiment was done under trial area of Univ- 
eristy of Agriculture Faisalabad. Main purpose of this is to note different abiotic factors under different conditions. All the results noted by using graphical data as well to get better and accurate result.

\section{Author's Contribution}

Tamoor Ali: Did Experiments.

Muhammad Hamid Bashir, Bilal Saeed Khan, Ikram U1 Haq and Abdul Ghaffar: Supervised the experiment.

Danish Riaz, Muhammad Zia ul Haq, Shoaib Nawaz, Aneeb Ali, Iftikhar ul Hassan, Muhammad Khuram Shahzad, Usama Saleem and Tamsila

Nazi: Supported throughout experiment.

\section{Conflict of interest}

The authors have declared no conflict of interest.

\section{References}

Aheer, G.M., Ghani,A. and Ali, A., 1999. Population of whitefly, Bemisia tabaci (Genn.) and its natural enemies on cotton crop at Bahawalpur. Pak. Entomol., 21: 47-49.

Aheer, G.M., Ali, A. and Hussain, S. 2006. Varietal resistance against jassid, Amrasca devastans Dist. in cotton and role of abiotic factors in population fluctuation.J. Agric. Res., (Pakistan).

Akram, M., Hafeez, F., Farooq, M., Arshad, M., Hussain, M., Ahmed, S., Zia, K., and Khan, H.Z.A., 2013. A case to study population dynamics of Bemisia tabaci and Thrips tabaci on Bt and non-Bt cotton genotypes. Pak. J. Agric. Sci., 50: 617-623.

Ali, A. and Aheer, G.M., 2007. Varietal resistance against sucking insect pests of cotton under Bahawalpur ecological conditions. Pak. J. Agric. Sci., 45: 1-5.

Ali, A., Bhatti, M.A., and Ahmad, K.J., 1993. Role of weather in fluctuating the population of Amrasca devastans (Dist.) and Thrips tabaci (Lind.). Proc. Pak. Cong. Zool., 13: 133-139.

Amin, M.R., Ahad, M.A., Hossain, M.H., Hossain, S.M.A. and Tithi, D.A. 2008. Characteristics of some cotton varieties in relation to seasonal abundance of pests, predators and their impact on yield and quality. J. Agrofor. Environ., 2(2): 67-70.

Anonymous, 2018. Economic survey, Govt. Pakistan, Fin. Div. Adv. Wing, Islamabad.
Arif, M.J., Gogi,M.D., Mirza, M., Zia, K., and Hafeez, F., 2006. Impact of plant spacing and abiotic factors on population dynamics of sucking insect pests of cotton. Pak. J. Biol. Sci., 9(7): 1364-1369. https://doi.org/10.3923/ pjbs.2006.1364.1369

Ashfaq, M., Noor-ul-Ane, M., Zia, K., Nasreen , A. and Mansoor-ul-Hasan. 2010. The correlation of abiotic factors and physico-morphic characteristics of (Bacillus thuringiensis) $\mathrm{Bt}$ transgenic cotton with whitefly, Bemisia tabaci (Homoptera, Aleyrodidae) and jassid, Amrasca devastans (Homoptera, Jassidae) populations. Afr.J. Agric. Res., 5(22): 3102-3107.

Bala, C.S., R. Nihal and A. Sarkar. 2019. Population dynamics of whitefly (Bemisia tabaci, Genn.) and Thrips (Scirtothrips dorsalis, Hood.) in Bt cotton. J. Entomol. Zool. Studies, 7(2): 10201024.

Gupta, M.P., Sandeep, S., Shrivastava, S.K. and Sharm, S., 1997. Population build-up of some sap sucking insects on cotton in Madhya Pardesh. J. Insect Sci., 10: 153-156.

Harrison, B.D., Liu, Y.L., Khalid, S., Hameed, S., Otim-Nape, G.W. and Robinson, D.J., 1997. Detection and relationships of cotton leaf curl virus and allied whitefly transmitted Gemini viruses occurring in Pakistan. Ann. Appl. Biol., 130: 61-75. https://doi. org/10.1111/j.1744-7348.1997.tb05783.x

Inee-Gogoi, B., Dutta, C. and Gogoi, I., 2000. Seasonal abundance of cotton jassid, Amrasca biguttula biguttula Ishida on okra. J. Agric. Sci., 13: 22-26.

Khanzada, M.S., Syed, T.S., Rani, S., Khanzada, G.H.A., Salman, M., Anwar, S. and Abro, A.H. 2016. Occurrence and abundance of thrips, whitefly and their natural enemy, Geocoris Spp. on cotton crop at various localities of Sindh, Pakistan.J. Entomol. Zool. Stud., 4: 509-515.

Mahmood, T., Hussain, S.I., Khokar, K.M., Jeelani, G. and Ahmad, M., 2002. Population dynamics of leafhopper (Amrasca biguttula biguttula) on brinjal and effect of abiotic factors on its dynamics.Asian J. Plant Sci., 4: 403-404. https:// doi.org/10.3923/ajps.2002.403.404

Mohapatra, L.N., 2008. Population dynamics of sucking pests in birsutum cotton and influence of weather parameters on its incidence in western Orissa.J. Cotton Res. Dev., 22: 192-194. Saleem, M.J., Hafeez, F., Arshad, M., Atta, B., 
Maan, N.A., Ayub, M.A. and Zubair, M., 2018. Population dynamics of sucking pests on transgenic $\mathrm{Bt}$ cotton in relation with abiotic factors and physio-morphological plant characters. J. Entomol. Zool. Stud., 6(6): 163166.

Salman, M., Masood, A., Arif, M.J., Saeed, S. and Hamed, M., 2011. The resistance levels of different cotton varieties against sucking insect pests complex in Pakistan. Pak. J. Agric. Agric. Eng. Vet. Sci., 27: 168-175.

Shah, S.I.A., 2014. The cotton stainer (Dysdercus koenigii), An emerging serious threat for cotton crop in Pakistan. Pak.J. Zool., 46: 329-335.

Siddique, M.K., Syed, T.S., Khanzad, S.R., Abro,
G.H., Salman, M. and Anwar, S., 2016. Occurrence and abundance of thrips, whitefly and their natural enemy Geocoris spp. on cotton crop at various localities of Sindhu. Pak. J. Entomol. Zool. Stud., 4(1): 509-515.

Suvash, C.B., Nihal, R. and Anirban, S., 2019. Population dynamics of whitefly (Bemisia tabaci, Genn.) and Thrips (Scirtothrips dorsalis, Hood.) in Bt cotton. J. Entomol. Zool. Stud., 7(2): 1020-1024.

Yousafi, Q., Afzal, M., Aslam, M., Razzaq, M. and Shahid, M., 2013. Screening of brinjal (Solanum melongena L.) varieties sown in autumn for resistance to cotton jassid, Amrasca bigutulla bigutulla (Ishida). Pak. J. Zool., 45: 897-902. 